\title{
Salicylic Acid as a Safe Plant Protector and Growth Regulator
}

\author{
Young Mo Koo, A Yeong Heo, and Hyong Woo Choi* \\ Department of Plant Medicals, Andong National University, Andong 36729, Korea \\ (Received on December 16, 2019; Revised on January 27, 2020; Accepted on January 27, 2020)
}

Since salicylic acid (SA) was discovered as an elicitor of tobacco plants inducing the resistance against Tobacco mosaic virus (TMV) in 1979, increasing reports suggest that SA indeed is a key plant hormone regulating plant immunity. In addition, recent studies indicate that SA can regulate many different responses, such as tolerance to abiotic stress, plant growth and development, and soil microbiome. In this review, we focused on the recent findings on SA's effects on resistance to biotic stresses in different plant-pathogen systems, tolerance to different abiotic stresses in different plants, plant growth and development, and soil microbiome. This allows us to discuss about the safe and practical use of $\mathrm{SA}$ as a plant defense activator and growth regulator. Crosstalk of SA with different plant hormones, such as abscisic acid, ethylene, jasmonic acid, and auxin in different stress and developmental conditions were also discussed.

Keywords : abiotic stress tolerance, resistance, salicylic acid, susceptibility

Handling Editor : Chang-Jin Park

As a sessile organism, plant growth and response to environmental cues are largely governed by plant hormones, also called phytohormones. Phytohormones act spatially

\footnotetext{
*Corresponding author.

Phone) +82-54-829-5509, FAX) +82-54-820-6320

E-mail)hwchoi@anu.ac.kr

ORCID

Hyong Woo Choi

https://orcid.org/0000-0001-6049-4426

(c) This is an Open Access article distributed under the terms of the Creative Commons Attribution Non-Commercial License (http:// creativecommons.org/licenses/by-nc/4.0) which permits unrestricted noncommercial use, distribution, and reproduction in any medium, provided the original work is properly cited.
}

Articles can be freely viewed online at www.ppjonline.org. and temporally as endogenous signals at a very low dose to regulate various physiological functions. Unlike the animal systems producing hormones in specialized organs and transferring them to another parts via blood stream, each living plant cell can produce hormones on their own (Went and Thimann, 1937). To successfully survive under the biotic and abiotic stress conditions, plants evolved highly sophisticated crosstalk between different phytohormones. Fine-tuning of complex phytohormone network enables the balanced response of plants to developmental and environmental cues, thus minimizing defense-associated fitness costs. Harmony and/or disharmony of phytohormones, such as jasmonic acid (JA), ethylene (ET), abscisic acid (ABA), auxin (IAA), and salicylic acid (SA), result in specific response to specific stimuli.

Phytohormones JA and ET play a pivotal role in the regulation of plant immune response against necrotrophic pathogens and herbivory insect pathogens (Wasternack and Song, 2017). JA is biosynthesized from $\alpha$-linolenic acid via octadecanoid pathway. During the activation of JA signaling, JA stimulates interaction of coronatine-insensitive 1 (COI1), which is a component of $\mathrm{SCF}^{\mathrm{COI1}} \mathrm{E} 3$ ubiquitin ligase complex, with jasmonate-zim-domain (JAZ) proteins, a suppressor of JA-responsive transcription factors (TFs; e.g., MYC2). This JA-induced interaction between COI1 and JAZs facilitate degradation of JAZs through the $26 \mathrm{~S}$ proteasome, thereby releasing downstream TFs to regulate gene expression and activate JA responses. ET, a gaseous plant hormone, is biosynthesized from $S$-adenosylmethionine via the action of two key enzymes ACC synthase and ACC oxidase (Wang et al., 2002). It regulates many different aspects of the plant physiology, including germination, senescence, abscission, fruit ripening, and response to biotic and abiotic stresses. Five ethylene receptor genes (ETHYLENE RESPONSE1 [ETR1], ETHYLENE RESPONSE SENSOR1 [ERS1], ETR2, ETHYLENE INSENSITIVE4 [EIN4], and ERS2) are identified from the Arabidopsis plants (Ju and Chang, 2015). Mutant plant lacks JA/ ET signaling showed highly susceptible phenotype against 
infection by necrotrophic pathogens and infestation by herbivory insect pathogens.

$\mathrm{ABA}$, a sesquiterpenoid hormone, is biosynthesized from $\mathrm{C}_{40}$ epoxycarotenoid precursors through an oxidative cleavage reaction in plastids (Xiong and Zhu, 2003). The $\mathrm{C}_{15}$ intermediate xanthoxin is converted to ABA by a two-step reaction via $\mathrm{ABA}$-aldehyde oxidase in cytosol. ABA plays an important role in many cellular processes including seed development, dormancy, germination, and water stress responses (Ng et al., 2014). In the absence of ABA signaling, type $2 \mathrm{C}$ protein phosphatases (PP2Cs) constitutively dephosphorylate Snf1-related protein kinases 2 (SnRK2). In response to $\mathrm{ABA}$ signal, regulatory component of $\mathrm{ABA}$ receptor (RCAR)/pyrabactin resistance (PYR)/PYR1-like (PYLs) proteins, collectively termed PYLs, bind and inhibit PP2Cs. Inhibition PP2Cs in turn allows SnRK2 activation through autophosphorylation. Active SnRK2 mediate the downstream ABA response through the phosphorylation of target proteins (e.g., slow-type anion channel [SLAC1] and inward-rectifying potassium channel [KAT1]).

Both IAA and SA are synthesized from shikimate pathway (Pérez-Llorca et al., 2019). In the first step, shikimate is converted into chorismate by chorismate synthase. For IAA and SA biosynthesis, chorismate is further converted into either tryptophan (Trp) or isochorismate, respectively. Then, Trp is converted into IAA through several reaction steps, including the conversion of Trp to indole-3-pyruvic acid by the tryptophan aminotransferase. IAA plays an essential role in almost every aspect of plant growth and development processes, including the cell division and differentiation, as well as in biotic and abiotic stress responses (Korver et al., 2018; Pérez-Llorca et al., 2019). Perception of IAA via its cognate receptor TRANSPORT INHIBITOR RESPONSE1 (TIR1), the F-box subunit of the ubiquitin ligase complex $\mathrm{SCF}^{\mathrm{TIR} 1}$, stabilizes the interaction between TIR1 and Aux/IAA proteins. This interaction results in Aux/IAA ubiquitination and subsequent degradation. Degradation of Aux/IAA led to release and activation of AUXIN RESPONSE FACTOR proteins for activation of downstream IAA signaling.

SA is biosynthesized from the chorismate via two independent pathways, isochorismate synthase- and phenylalanine ammonia-lyase-dependent pathways (Dempsey and Klessig, 2017). Role of SA in plant defense response has only become evident during the past 30 years. Before SA is recognized as an important plant hormone, it was assumed to be relatively unimportant products together with many other phenolic secondary metabolites. However, the findings regarding (1) enhanced resistance phenotype in SAtreated tobacco plants against Tobacco mosaic virus (TMV) infection, and (2) over 20-fold increase in endogenous SA level in TMV-infected resistant tobacco plants boost the researches on SA as a plant hormone regulating disease resistance (Klessig et al., 2018). Increasing reports suggest that SA plays important roles not only in regulating plant disease resistance, but also in thermogenesis, abiotic stress tolerance, DNA damage/repair, fruit yield, seed germination, and etc. (Dempsey and Klessig, 2017). In this review, we focused on the diverse effect of SA on different aspect of plant phenotypes in relation with other plant hormones. For SA-mediated defense signaling pathway at the molecular level, we recommend to read reviews by $\mathrm{Lu}(2009)$, Yan and Dong (2014), and Zhang and Li (2019).

\section{SA and JA/ET in Plant Resistance to Biotic Stresses}

SA is a defense-related plant hormone that plays a key role in resistance to different microbial pathogens, such as virus, bacteria, fungi, and oomycetes (Kunkel and Brooks, 2002; Vlot et al., 2009). In plants, the positive correlation between endogenous levels of SA and resistance responses against biotrophic and hemibiotrophic pathogens are well established (Glazebrook, 2005). In addition, the exogenous SA application induces local and systemic acquired resistance in different plant species against various types of pathogens, including Fusarium oxysporum, Alternaria alternata, Magnaporthe grisea, Colletotrichum gloeosporides, Xanthomonas spp., different kinds of viruses and etc. (Table 1) (Daw et al., 2008; Esmailzadeh et al., 2008; Jendoubi et al., 2017; Kundu et al., 2011; Le Thanh et al., 2017; Mohan Babu et al., 2003; Radwan et al., 2007; Saikia et al., 2003; Wang and Liu, 2012; Wang et al., 2006). Notably, exogenous application of $1 \mathrm{mM}$ SA almost completely suppressed powdery mildew disease development in cucumber plants (Fig. 1). However, SA's roles in plant defense against necrotrophic pathogens are not fully understood yet, due to its complexity. JA and ET are known to be essential for plant resistant against necrotrophic pathogens (Erb et al., 2012; Wang et al., 2015a). Among different plants-necrotrophic pathogens interactions, a few cases of exogenous SA treatment-induced enhanced susceptibility was reported (Table 2). In broad bean, SA treatment compromised red light-induced resistance against the necrotrophic pathogen Botrytis cinerea; however, it does not further enhanced dark light-induced susceptibility (Khanam et al., 2005). Application of SA-induced enhanced susceptibility in tomato against $B$. cinerea in a dose-dependent manner. Controversially, the SA-induced enhanced resistance of tomato and Arabidopsis plants against $B$. cinerea is also reported (Ferrari et al., 2003; Li and Zou, 2017). Generally, 
Table 1. Enhanced disease resistance upon exogenous SA application in different plants

\begin{tabular}{|c|c|c|c|c|}
\hline Host plant & Pathogen (infection style) & $\begin{array}{l}\text { SA conc. and } \\
\text { treatment method }\end{array}$ & Effect & References \\
\hline \multirow{4}{*}{$\begin{array}{l}\text { Tomato } \\
\text { (Lycopersicon } \\
\text { esculentum) }\end{array}$} & $\begin{array}{l}\text { Fusarium oxysporum } \\
\text { (hemibiotrophic) }\end{array}$ & $0.2 \mathrm{mM}$ & $\sim 55 \%$ reduction in disease incidence & $\begin{array}{l}\text { Jendoubi et al. } \\
\text { (2017) }\end{array}$ \\
\hline & $\begin{array}{l}\text { Botrytis cinerea } \\
\text { (necrotrophic) }\end{array}$ & $2 \mathrm{mM}$ & $\sim 62 \%$ reduction in disease severity & $\begin{array}{l}\text { Li and Zou } \\
(2017)\end{array}$ \\
\hline & $\begin{array}{l}\text { Alternaria alternata } \\
\text { (necrotrophic) }\end{array}$ & $0.4 \mathrm{mM}$ & $\sim 57 \%$ reduction in disease severity & $\begin{array}{l}\text { Esmailzadeh } \\
\text { et al. (2008) }\end{array}$ \\
\hline & $\begin{array}{l}\text { Potato purple top }(\mathrm{PPT}) \\
\text { phytoplasma } \\
\text { (biotrophic) }\end{array}$ & $\begin{array}{l}100 \mathrm{ml} \text { of } 0.1 \mathrm{mM} \\
\mathrm{SA} \text { is sprayed and } \\
100 \mathrm{ml} \text { of } 0.1 \mathrm{mM} \\
\text { soil-drenched }\end{array}$ & $\sim 47 \%$ reduction in disease incidence & Wu et al. (2012) \\
\hline \multirow[t]{2}{*}{$\begin{array}{l}\text { Pepper } \\
\text { (Capsicum annuum) }\end{array}$} & $\begin{array}{l}\text { Ralstonia solanacearum } \\
\text { (hemibiotrophic) }\end{array}$ & $0.5 \mathrm{mM}$ & $\begin{array}{l}\text { R. solanacearum-induced seedling growth } \\
\text { inhibition is recovered. Notably, } 0.5 \mathrm{mM} \mathrm{SA} \\
\text { itself enhanced seedling growth by } \sim 150 \%\end{array}$ & $\begin{array}{l}\text { Chandrasekhar } \\
\text { et al. (2017) }\end{array}$ \\
\hline & $\begin{array}{l}\text { Fusarium oxysporum } \\
\text { (hemibiotrophic) }\end{array}$ & $0.5 \mathrm{mg} / \mathrm{l}$ & $\sim 50 \%$ reduction in disease incidence & Yousif(2018) \\
\hline \multirow[t]{4}{*}{$\begin{array}{l}\text { Rice } \\
(\text { Oryza sativa })\end{array}$} & $\begin{array}{l}\text { Magnaporthe grisea } \\
\text { (hemibiotrophic) }\end{array}$ & $8 \mathrm{mM}$ & $\sim 70 \%$ reduction in disease severity & $\begin{array}{l}\text { Daw et al. } \\
(2008)\end{array}$ \\
\hline & $\begin{array}{l}\text { Xanthomonas oryzae } \\
\text { (hemibiotrophic) }\end{array}$ & $1 \mathrm{mM}$ & Leaf blight lesion length is reduced & $\begin{array}{l}\text { Mohan Babu } \\
\text { et al. }(2003)\end{array}$ \\
\hline & & $1 \mathrm{mM}$ & $\sim 30 \%$ reduction in disease severity & $\begin{array}{l}\text { Le Thanh et al. } \\
\text { (2017) }\end{array}$ \\
\hline & $\begin{array}{l}\text { Oebalus pugnax } \\
\text { (piercing and sucking } \\
\text { insect) }\end{array}$ & $16 \mathrm{mM}$ & $\begin{array}{l}\sim 35 \% \text { reduction in number of bugs found in } \\
\text { plots; retarded nymph development to adult } \\
\text { insect }\end{array}$ & $\begin{array}{l}\text { Stella de Freitas } \\
\text { et al. (2019) }\end{array}$ \\
\hline $\begin{array}{l}\text { Orange } \\
\text { (Citrus sinensis) }\end{array}$ & $\begin{array}{l}\text { Xanthomonas axonopodis } \\
\text { (biotrophic) }\end{array}$ & $0.25 \mathrm{mM}$ & $\sim 45 \%$ reduction in disease incidence & $\begin{array}{l}\text { Wang and Liu } \\
\text { (2012) }\end{array}$ \\
\hline $\begin{array}{l}\text { Banana } \\
\text { (Musa acuminata) }\end{array}$ & $\begin{array}{l}\text { Fusarium oxysporum } \\
\text { (hemibiotrophic) }\end{array}$ & $\begin{array}{l}\text { Roots were dipped } \\
\text { in } 0.1 \mathrm{mM} \mathrm{SA} \text { for } \\
2 \text { days }\end{array}$ & $\begin{array}{l}\text { Disease symptom (corm browning) is not } \\
\text { observed } 3 \text { weeks after inoculation with the } \\
\text { pathogen } \\
\text { Note, } 0.2 \mathrm{mM} \mathrm{SA} \text {-induced necrosis on roots }\end{array}$ & $\begin{array}{l}\text { Wang et al. } \\
(2015 b)\end{array}$ \\
\hline \multirow[t]{2}{*}{$\begin{array}{l}\text { Chickpea } \\
\text { (Cicer arietinum) }\end{array}$} & $\begin{array}{l}\text { Fusarium oxysporum } \\
\text { (hemibiotrophic) }\end{array}$ & $\begin{array}{l}10 \mu l \text { of } \sim 14.5 \mathrm{mM} \\
\text { SA is injected at the } \\
\text { base of stem }\end{array}$ & $\begin{array}{l}\sim 20 \% \text { reduction in disease severity } \\
\text { (also increased } \sim 6 \% \text { in both shoot and root } \\
\text { growth length) }\end{array}$ & $\begin{array}{l}\text { Saikia et al. } \\
(2003)\end{array}$ \\
\hline & & $\begin{array}{l}10 \mathrm{ml} \text { of } \sim 0.58 \mathrm{mM} \\
\mathrm{SA} \text { is soil-drenched }\end{array}$ & $\begin{array}{l}\sim 20 \% \text { reduction in disease severity } \\
\text { (also increased } \sim 10 \text { and } 4.5 \% \text { in shoot and } \\
\text { root growth length, respectively) }\end{array}$ & \\
\hline $\begin{array}{l}\text { Black gram or } \\
\text { urdbean } \\
\text { (Vigna mungo) }\end{array}$ & $\begin{array}{l}\text { Mungbean yellow mosaic } \\
\text { Indian virus (MYMIV) } \\
\text { (biotrophic) }\end{array}$ & $0.1 \mathrm{mM}$ & $\sim 71 \%$ reduction in disease severity & $\begin{array}{l}\text { Kundu et al. } \\
\text { (2011) }\end{array}$ \\
\hline $\begin{array}{l}\text { Pumpkin } \\
\text { (Cucurbita pepo) }\end{array}$ & $\begin{array}{l}\text { Zucchini yellow mosaic } \\
\text { virus (ZYMV) (biotrophic) }\end{array}$ & $0.1 \mathrm{mM}$ & $\sim 66 \%$ reduction in disease severity & $\begin{array}{l}\text { Radwan et al. } \\
(2007)\end{array}$ \\
\hline $\begin{array}{l}\text { Peanut } \\
\text { (Arachis hypogaea) }\end{array}$ & $\begin{array}{l}\text { Peanut mottle virus } \\
\text { (PeMoV) (biotrophic) }\end{array}$ & $0.2 \mathrm{mM}$ & $\sim 42 \%$ reduction in disease severity & $\begin{array}{l}\text { Kobeasy et al. } \\
(2011)\end{array}$ \\
\hline $\begin{array}{l}\text { Tea flower } \\
\text { (Camelia oleifera) }\end{array}$ & $\begin{array}{l}\text { Colletotrichum gloeospori- } \\
\text { oides (hemibiotrophic) }\end{array}$ & $\sim 1 \mathrm{mM}$ & $>40 \%$ reduction in disease severity & $\begin{array}{l}\text { Wang et al. } \\
(2006)\end{array}$ \\
\hline $\begin{array}{l}\text { Rubber tree } \\
\text { (Hevea brasiliensis) }\end{array}$ & $\begin{array}{l}\text { Phytophthora palmivora } \\
\text { (hemibiotrophic) }\end{array}$ & $5 \mathrm{mM}$ & $\begin{array}{l}\sim 41 \% \text { reduction in disease severity } \\
\text { (>10 mM SA-induced leaf shrinkage) }\end{array}$ & $\begin{array}{l}\text { Deenamo et al. } \\
\text { (2018) }\end{array}$ \\
\hline $\begin{array}{l}\text { Arabidopsis } \\
\text { (Arabidopsis thaliana) }\end{array}$ & $\begin{array}{l}\text { Botrytis cinerea } \\
\text { (necrotrophic) }\end{array}$ & $5 \mathrm{mM}$ & $\sim 62 \%$ reduction in lesion size & $\begin{array}{l}\text { Ferrari et al. } \\
(2003)\end{array}$ \\
\hline
\end{tabular}

SA, salicylic acid. 

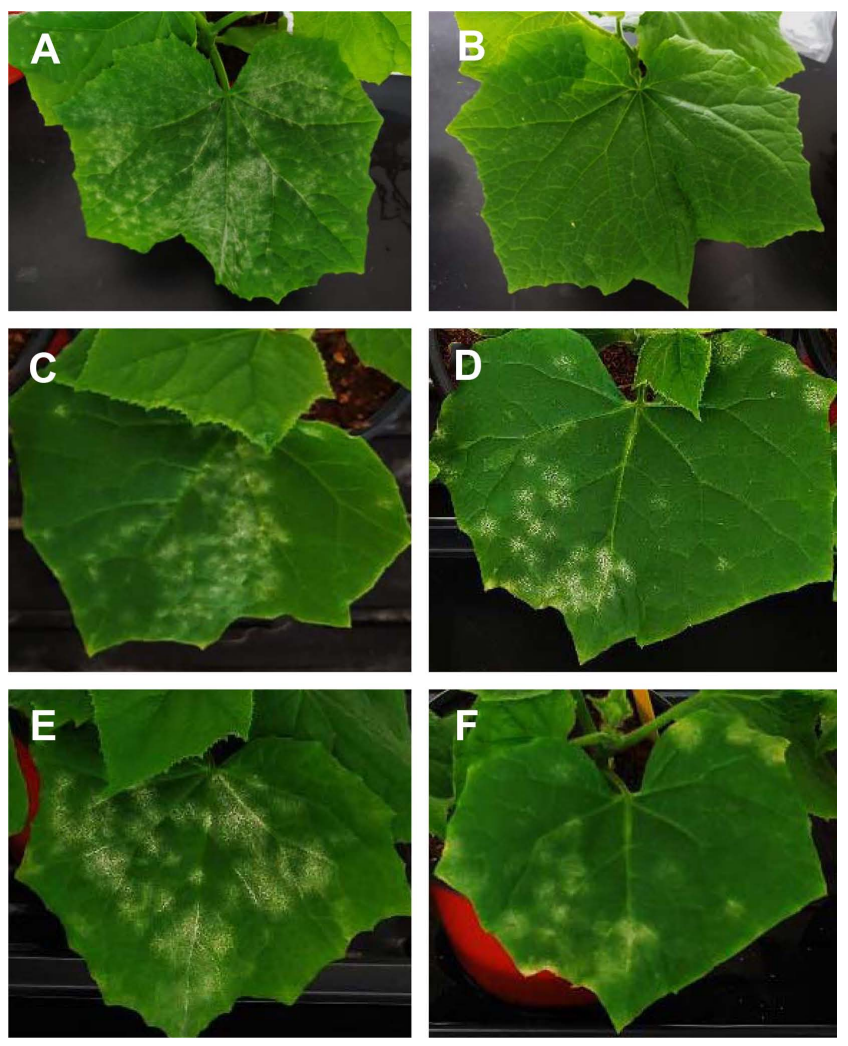

Fig. 1. Enhanced resistance of cucumber plants against powdery mildew disease by exogenous salicylic acid (SA) treatment. (A, B) Powdery mildew disease symptom developed 7 days after inoculation. Before the pathogen inoculation, cucumber plants were sprayed with steriled tap water (A) or $1 \mathrm{mM} \mathrm{SA}(\mathrm{B})$. (C-F) Disease control effect of SA. (C, D) Cucumber leaves developing powdery mildew disease symptoms before the SA treatment. $(\mathrm{E}, \mathrm{F})$ Disease progression was observed 7 days after spray with steriled tap water (E) or $1 \mathrm{mM}$ SA (F). SA effectively suppressed new infection (B) and disease progression (F) in cucumber plants.
SA-dependent defense singling is known to be antagonistic against JA-/ET-dependent defense signaling (Glazebrook, 2005). However, the hormone signaling pathways between SA and ET/JA are not exclusively antagonistic (RobertSeilaniantz et al., 2011), thus it needs to be carefully analyzed in different plant-pathogen systems and field conditions.

\section{SA and ABA in Plant Tolerance to Abiotic Stresses}

Continuous cropping and climate change threaten plant production via multiple abiotic stresses induced by heavy metals, salinity, ozone, ultraviolet, temperature and drought (Connor, 2002). Intriguingly, SA is not only regulating the resistance to biotic stresses, but also the tolerance to various abiotic stresses (Horváth et al., 2007; Khan et al., 2015) (Table 3). The underlying mechanisms of SA-induced abiotic stress tolerance include that SA-mediated (1) accumulation of osmolytes, such as glycinebetaine, proline, soluble sugars and amines, which can help maintain osmotic homeostasis, (2) regulation of mineral nutrition uptake, (3) enhanced reactive oxygen species scavenging activity, (4) enhanced secondary metabolite production, such as terpenes, phenolics, and compounds with nitrogen (alkaloids, cyanogenic glucosides, non-protein amino acids) and sulfur (glutathione, glucosinolates, phytoalexins, thionins, defensins, and allinin), and (5) regulation of other hormone pathways (Horváth et al., 2007; Khan et al., 2015).

Exogenous SA treatment induces the expression of a set of pathogenesis-related $(P R)$ genes, including $P R 1, P R 2$, and $P R 5$ (Ali et al., 2018). Interestingly, transgenic overexpression of some $P R$ genes not only enhanced the resistance to different pathogens, but also enhanced the tolerance to different abiotic stresses (Hong and Hwang, 2005;

Table 2. Enhanced disease susceptibility upon exogenous SA application in different plants

\begin{tabular}{|c|c|c|c|c|}
\hline Host plant & $\begin{array}{c}\text { Pathogen } \\
\text { (infection style) }\end{array}$ & SA conc. and treatment method & Effect & References \\
\hline $\begin{array}{l}\text { Tomato } \\
\text { (Lycopersicon } \\
\text { esculentum) }\end{array}$ & $\begin{array}{l}\text { Botrytis cinerea } \\
\text { (necrotrophic) }\end{array}$ & $0.05,0.5$, and $2.5 \mathrm{mM}$ & $\begin{array}{l}\text { Lesion size are increased by } \sim 325 \text {, } \\
416 \text {, and } 425 \% \text {, respectively }\end{array}$ & El Oirdi et al. (2011) \\
\hline \multirow[t]{2}{*}{$\begin{array}{l}\text { Broad bean } \\
\text { (Vicia faba) }\end{array}$} & $\begin{array}{l}\text { Botrytis cinerea } \\
\text { (necrotrophic) }\end{array}$ & $\begin{array}{l}0.05-1 \mathrm{mM} \\
\text { (under red light }=\text { resistance } \\
\text { inducing condition) }\end{array}$ & $\begin{array}{l}\sim 746 \% \text { increase in disease severity } \\
\text { by } 1 \mathrm{mM} \mathrm{SA}\end{array}$ & Khanam et al. (2005) \\
\hline & & $\begin{array}{l}0.05-1 \mathrm{mM} \\
\text { (under dark = disease inducing } \\
\text { condition) }\end{array}$ & $\begin{array}{l}\text { No significant difference in disease } \\
\text { severity upto } 1 \mathrm{mM} \mathrm{SA}\end{array}$ & \\
\hline
\end{tabular}

SA, salicylic acid. 
Table 3. Enhanced abiotic stress upon exogenous SA application in different plants

\begin{tabular}{|c|c|c|c|c|}
\hline Host plant & Stress & SA conc. and treatment method & Effect & References \\
\hline $\begin{array}{l}\text { Tomato } \\
\text { (Lycopersicon } \\
\text { esculentum) and } \\
\text { Bean (Phaseolus } \\
\text { vulgaris) }\end{array}$ & $\begin{array}{l}\text { Heat/ } \\
\text { chilling/ } \\
\text { drought }\end{array}$ & $\begin{array}{l}\text { Seed imbibed or soil drenched } \\
\text { with } 0.05,0.1,0.5 \text {, and } 1 \mathrm{mM} \mathrm{SA}\end{array}$ & $\begin{array}{l}\text { Upon heat, chilling, and drought stress treatments, } \\
\text { untreated control or } 0.05 \text { and } 1.0 \mathrm{mM} \mathrm{SA} \text {-treated } \\
\text { plants died } 100 \% \text {, while } 0.1 \text { and } 0.5 \mathrm{mM} \mathrm{SA} \text { - } \\
\text { treated plants survived } 100 \%\end{array}$ & $\begin{array}{l}\text { Senaratna et al. } \\
(2000)\end{array}$ \\
\hline $\begin{array}{l}\text { Tomato } \\
\text { (Lycopersicon } \\
\text { esculentum) }\end{array}$ & Salt & $\begin{array}{l}0.1 \mathrm{mM} \text { SA is added in hydro- } \\
\text { ponic cluture solution ( } 3 \text { weeks) }\end{array}$ & $\begin{array}{l}\text { Photosynthetic activity is partially recovered. } \\
\text { Endogenous ABA content is increased }\end{array}$ & $\begin{array}{l}\text { Horváth et al. } \\
(2015)\end{array}$ \\
\hline $\begin{array}{l}\text { Corn } \\
\text { (Zea mays) }\end{array}$ & $\begin{array}{l}\text { Cadmium } \\
(\mathrm{Cd})\end{array}$ & SI with $0.5 \mathrm{mM}$ SA for $6 \mathrm{~h}$ & $\begin{array}{l}\text { Shoot } \mathrm{FW} \text { and root DW are increased by } \\
\sim 262 \% \text { and } \sim 121 \% \text {, respectively. However, } \\
\text { SA treatment itself reduced shoot FW by } 27 \%\end{array}$ & $\begin{array}{l}\text { Krantev et al. } \\
(2008)\end{array}$ \\
\hline \multirow[t]{2}{*}{$\begin{array}{l}\text { Barley } \\
\text { (Hordeum vulgare) }\end{array}$} & $\begin{array}{l}\text { Cadmium } \\
(\mathrm{Cd})\end{array}$ & SI with $0.5 \mathrm{mM}$ SA for $6 \mathrm{~h}$ & $\begin{array}{l}\text { Shoot and root FW are increased by } \sim 133 \% \text { and } \\
\sim 127 \% \text {, respectively. However, SA treatment } \\
\text { itself reduced shoot and root FW by } 22 \% \text { and } \\
12 \% \text {, respectively }\end{array}$ & $\begin{array}{l}\text { Metwally et al. } \\
(2003)\end{array}$ \\
\hline & $\begin{array}{l}\text { Osmotic } \\
\text { stress }\end{array}$ & $\begin{array}{l}\text { The root systems of } 20 \text {-day-old } \\
\text { seed lings were } \\
\text { immersed in aerated solutions of } \\
30,60 \text {, and } 120 \mathrm{nM} \mathrm{SA} \text { for } 24 \mathrm{~h}\end{array}$ & $\begin{array}{l}\text { Osmotic stress-induced membrane injury (cell } \\
\text { death) reduced by } \sim 50 \% \text {. Endogenous ABA } \\
\text { content is increased }\end{array}$ & $\begin{array}{l}\text { Bandurska } \\
\text { and Stroiński } \\
(2005)\end{array}$ \\
\hline $\begin{array}{l}\text { Wheat } \\
\text { (Triticum aestivum) }\end{array}$ & Freezing & $\begin{array}{l}0.01,0.1 \text {, and } 1 \mathrm{mM} \text { SA sprayed } \\
\text { on wheat leaves at the four-leaf } \\
\text { stage three times, with an interval } \\
\text { of } 12 \mathrm{~h}\end{array}$ & $\begin{array}{l}0.01 \text { and } 0.1 \mathrm{mM} \mathrm{SA} \text { significantly inhibited } \\
\text { freezing stress-induced PS II quantum yield } \\
\text { reduction and cell death. SA enhanced production } \\
\text { of } \mathrm{ABA} \text { and } \mathrm{H}_{2} \mathrm{O}_{2}\end{array}$ & $\begin{array}{l}\text { Wang et al. } \\
\text { (2018) }\end{array}$ \\
\hline
\end{tabular}

SA, salicylic acid; ABA, abscisic acid; FW, fresh weight; DW, dry weight; PS II, photosystem II.

Sarowar et al., 2005; Wu et al., 2016). Transgenic tobacco overexpressing pepper $P R-1$ showed enhanced heavy metal tolerance (Sarowar et al., 2005). Overexpression of pepper $P R-1$ enhanced drought and salt stress tolerance in Arabidopsis plants (Hong and Hwang, 2005). However, the underlying molecular mechanisms on how these PR proteins enhancing the abiotic stress tolerance need further investigation.

ABA is known as a key plant hormone conferring abiotic stress tolerance, and it antagonistically regulates SAmediated defense signaling (Robert-Seilaniantz et al., 2011). ABA-induced suppression of SA-dependent signaling pathway often led to enhanced disease susceptibility in different plant-pathogen interactions (Audenaert et al., 2002; Jiang et al., 2010; Ulferts et al., 2015). However, under the certain abiotic stress conditions, such as freezing and salt stresses, ABA and SA together seems to be able to positively regulate stress tolerance response (Horváth et al., 2015; Szalai et al., 2011; Wang et al., 2018). Exogenous SA pretreatment significantly induced freezing tolerance of wheat via enhancing biosynthesis of ABA (Wang et al., 2018). In tomato plants, exogenous SA treatment-induced ABA biosynthesis in a dose-dependent manner, and partially recovered lowered photosynthetic activity under salt stress condition (Horváth et al., 2015). Pretreatment of barley plants with SA increased the ABA content and reduced the damage induced by water deficit condition (Bandurska and Stroiński, 2005). Notably, an important cluster of genes that are similarly regulated by ABA and SA $(28 \%$ of ABA-induced genes were also induced by SA, while $40 \%$ of ABA-repressed genes were also repressed by SA) is identified in Arabidopsis plants, suggesting plants equipped the common transcriptomic responses regulated by ABA and SA (Kalachova et al., 2016). Taken together, although ABA is antagonistically regulating the SA-mediated disease resistance, $\mathrm{ABA}$ and $\mathrm{SA}$ seem to be able to cooperate for developing abiotic stress tolerance.

\section{SA and IAA in Plant Growth and Development}

SA has controversial roles in plant growth and development depending on its concentration and plant growth conditions and developmental stages (Rivas-San Vicente and Plasencia, 2011). Generally, high levels of SA (It depends on the plant species, however, $>1 \mathrm{mM}$ SA considered as high concentration.) negatively regulate plant development and growth. Nevertheless, the application of optimal concentrations of SA showed beneficial effects 
on it. Depending on the experimental conditions, SA distinctly stimulated growth under both normal and different abiotic stress conditions in different plant species (Gunes et al., 2007; Gutiérrez-Coronado et al., 1998; Kováčik et al., 2009; Manzoor et al., 2015; Sakhabutdinova et al., 2003; Yildirim et al., 2008, 2015) (see also Table 3).

Exogenous SA application also showed different effects on plant development, including seed germination, budding, flowering, and fruit setting and ripening. In Finger Millet plants, SA stimulated flowering (Appu and Muthukrishnan, 2014). SA-induced enhanced fruit setting and weight were observed in strawberry (Kazemi, 2013), apple (Shaaban et al., 2011) and mango (Ngullie et al., 2014). Germination of barley and maize seeds imbibed in $>3 \mathrm{mM}$ SA were completely blocked (Guan and Scandalios, 1995; Xie et al., 2007). On the other hands, imbibing maize seeds in $\sim 0.3 \mathrm{mM}$ to $\sim 0.9 \mathrm{mM}$ SA showed higher germination speed, percentage and shoot length (Sallam and Ibrahim, 2015). Notably, $\sim 0.43 \mathrm{mM}$ SA exhibited the best germination stimulating effect, but its effect was decreased at the higher concentrations. Taken together, different concentrations of SA in different plants have either stimulating or blocking effects on plant development.

IAA influences plant growth and development, including tropic growth responses, vascular development, leaf and flower initiation, root growth, and lateral root formation. Recently, Pasternak et al. (2019) reported that SA regulates IAA biosynthesis and transport thereby changing the Arabidopsis root meristem patterning. Low-concentration SA (below $50 \mu \mathrm{M}$ ) promoted adventitious roots and altered architecture of the root apical meristem, whereas highconcentration SA (greater than $50 \mu \mathrm{M}$ ) inhibited overall growth processes in the root. Importantly, both SA and IAA are known to be biosynthesized from the shikimate pathway (Pérez-Llorca et al., 2019). This may suggest that higher biosynthetic activity of SA during the defense response may limit the resource required for the production of plant growth regulating hormone IAA, and vice versa, thereby fine-tuning the cost for the growth or defense depending on external and internal conditions.

\section{SA and Plant Microbiome}

Recently, researches on plant microbiome in relation with plant's health are getting more attention from plant science community (Bulgarelli et al., 2012; Lundberg et al., 2012). In model plant Arabidopsis thaliana, the effect of SA on microbiome was analyzed after exogenous SA application or by using the mutants with altered endogenous SA levels (Lebeis et al., 2015). It revealed that SA application distinctly enriched [Flavobacterium sp. 40 (Bacteroidetes) and Terracoccus sp. 273 (Actinobacteria)] and depleted [Mitsuaria sp. 370 ( $\beta$-Proteobacteria)] specific bacterial isolates from synthetic community (SynCom) experiment. In addition, population density of nine Actinobacteria and 12 Proteobacteria families were reduced and increased, respectively, in cpr 5 mutants that constitutively produces SA. This suggests that soil (and/or rhizosphere) microbiome can be distinctly altered by SA. So far, SA's effects on plants after soil drench application are majorly focused on induction of systemic immune response; however little is known about its effect on plant root or endophytic microbiomes. Thus further studies on SA's effects on diverse soil or endophytic microbiome will shed the lights on how SA influences different aspect of plant physiology, including immunity, growth, development and etc.

\section{Concluding Remarks and Perspectives}

Increasing numbers of reports suggesting that use of SA and its derivatives, collectively termed salicylates, reduces the risk of multiple chronic diseases in humans, including heart attack, stroke, arthritis, diabetes, certain type of cancers and Alzheimer's diseases (Castro-Torres et al., 2015; Chang et al., 2016; Rothwell et al., 2010; Steinberg et al., 2013; Tschanz et al., 2013). Given beneficial effects of SA on both plant and human health, SA and salicylates can be used as an efficient plant protector with very minor side effect on environments and humans. To use SA as an effective and environmentally friendly plant protector and/or plant growth regulator, following questions need to be addressed. First, the effective concentrations of SA for specific plants and/or purpose need to be determined. As mentioned above, high dose of SA ( $>2 \mathrm{mM})$ not only induces the enhanced disease resistance, but also has adverse effects on plant growth and productivity, which caused by undesirable balancing between cost and benefit of limited energy that plant can use. In humans, $>2.5 \mathrm{mM} \mathrm{SA}$ in the plasma lead to acute toxicity (Choi et al., 2015a, 2015b, 2019). Thus, SA concentrations ranging from micromolar $(\sim 100 \mu \mathrm{M})$ to low milimolar $(<2 \mathrm{mM})$ concentrations can be tested to screening the safe and effective concentrations for specific purpose. In addition, the use of high concentration of SA $(\sim 2 \mathrm{mM})$ as a plant growth regulator may also be considered, especially in case of growers need to reduce the growth rate of specific plants with disease control effect. Finally, natural SA derivatives, the amorfrutins, from the medicinal legume licorice Glycyrrhiza foetida, showed $\sim 1,000$ times stronger binding and inhibitory activities on selected SA-binding proteins (Choi et al., 2015b, 2019). 
Thus, the screening of salicylates with higher efficiency and specificity may warrant a novel plant protection method. Further studies on practical use of SA in different crop plants will contribute to developing the cost-effective and environmental friendly crop management system.

\section{Acknowledgments}

This work was supported by a Research Grant of Andong National University.

\section{References}

Ali, S., Ganai, B. A., Kamili, A. N., Bhat, A. A., Mir, Z. A., Bhat, J. A., Tyagi, A., Islam, S. T., Mushtaq, M., Yadav, P., Rawat, S. and Grover, A. 2018. Pathogenesis-related proteins and peptides as promising tools for engineering plants with multiple stress tolerance. Microbiol. Res. 212-213:29-37.

Appu, M. and Muthukrishnan, S. 2014. Foliar application of salicylic acid stimulates flowering and induce defense related proteins in finger millet plants. Univers. J. Plant Sci. 2:14-18.

Audenaert, K., De Meyer, G. B. and Höfte, M. M. 2002. Abscisic acid determines basal susceptibility of tomato to Botrytis cinerea and suppresses salicylic acid-dependent signaling mechanisms. Plant Physiol. 128:491-501.

Bandurska, H. and Stroiński, A. 2005. The effect of salicylic acid on barley response to water deficit. Acta Physiol. Plant. 27:379-386.

Bulgarelli, D., Rott, M., Schlaeppi, K., Ver Loren van Themaat, E., Ahmadinejad, N., Assenza, F., Rauf, P., Huettel, B., Reinhardt, R., Schmelzer, E., Peplies, J., Gloeckner, F. O., Amann, R., Eickhorst, T. and Schulze-Lefert, P. 2012. Revealing structure and assembly cues for Arabidopsis root-inhabiting bacterial microbiota. Nature 488:91-95.

Castro-Torres, Y., Katholi, R. E. and Yar Khan, N. 2015. Aspirin for primary prevention of cardiovascular diseases: current concepts, unanswered questions and future directions. $\mathrm{Hel}-$ lenic J. Cardiol. 56:461-474.

Chandrasekhar, B., Umesha, S. and Naveen Kumar, H. N. 2017. Proteomic analysis of salicylic acid enhanced disease resistance in bacterial wilt affected chilli (Capsicum annuum) crop. Physiol. Mol. Plant Pathol. 98:85-96.

Chang, C.-W., Horng, J.-T., Hsu, C.-C. and Chen, J.-M. 2016. Mean daily dosage of aspirin and the risk of incident alzheimer's dementia in patients with type 2 diabetes mellitus: a nationwide retrospective cohort study in Taiwan. J. Diabetes Res. 2016:9027484.

Choi, H. W., Tian, M., Manohar, M., Harraz, M. M., Park, S.W., Schroeder, F. C., Snyder, S. H. and Klessig, D. F. 2015a. Human GAPDH is a target of aspirin's primary metabolite salicylic acid and its derivatives. PLoS ONE 10:e143447.

Choi, H. W., Tian, M., Song, F., Venereau, E., Preti, A., Park, S.W., Hamilton, K., Swapna, G. V. T., Manohar, M., Moreau,
M., Agresti, A., Gorzanelli, A., De Marchis, F., Wang, H., Antonyak, M., Micikas, R. J., Gentile, D. R., Cerione, R. A., Schroeder, F. C., Montelione, G. T., Bianchi, M. E. and Klessig, D. F. 2015b. Aspirin's active metabolite salicylic acid targets high mobility group box 1 to modulate inflammatory responses. Mol. Med. 21:526-535.

Choi, H. W., Wang, L., Powell, A. F., Strickler, S. R., Wang, D., Dempsey, D. A., Schroeder, F. C. and Klessig, D. F. 2019. A genome-wide screen for human salicylic acid (SA)-binding proteins reveals targets through which SA may influence development of various diseases. Sci. Rep. 9:13084.

Connor, D. 2002. Climate change and global crop productivity. Crop Sci. 42:978.

Daw, B. D., Zhang, L. H. and Wang, Z. Z. 2008. Salicylic acid enhances antifungal resistance to Magnaporthe grisea in rice plants. Australas. Plant Pathol. 37:637-644.

Deenamo, N., Kuyyogsuy, A., Khompatara, K., Chanwun, T., Ekchaweng, K. and Churngchow, N. 2018. Salicylic acid induces resistance in rubber tree against Phytophthora palmivora. Int. J. Mol. Sci. 19:1883.

Dempsey, D. A. and Klessig, D. F. 2017. How does the multifaceted plant hormone salicylic acid combat disease in plants and are similar mechanisms utilized in humans? BMC Biol. 15:23.

El Oirdi, M., El Rahman, T. A., Rigano, L., El Hadrami, A., Rodriguez, M. C., Daayf, F., Vojnov, A. and Bouarab, K. 2011. Botrytis cinerea manipulates the antagonistic effects between immune pathways to promote disease development in tomato. Plant Cell 23:2405-2421.

Erb, M., Meldau, S. and Howe, G. A. 2012. Role of phytohormones in insect-specific plant reactions. Trends Plant Sci. 17:250-259.

Esmailzadeh, M., Soleimani, M. J. and Rouhani, H. 2008. Exogenous applications of salicylic acid for inducing systemic acquired resistance against tomato stem canker disease. J. Biol. Sci. 8:1039-1044.

Ferrari, S., Plotnikova, J. M., De Lorenzo, G. and Ausubel, F. M. 2003. Arabidopsis local resistance to Botrytis cinerea involves salicylic acid and camalexin and requires EDS4 and PAD2, but not SID2, EDS5 or PAD4. Plant J. 35:193-205.

Glazebrook, J. 2005. Contrasting mechanisms of defense against biotrophic and necrotrophic pathogens. Annu. Rev. Phytopathol. 43:205-227.

Guan, L. and Scandalios, J. G. 1995. Developmentally related responses of maize catalase genes to salicylic acid. Proc. Natl. Acad. Sci. U. S. A. 92:5930-5934.

Gunes, A., Inal, A., Alpaslan, M., Eraslan, F., Bagci, E. G. and Cicek, N. 2007. Salicylic acid induced changes on some physiological parameters symptomatic for oxidative stress and mineral nutrition in maize (Zea mays L.) grown under salinity. J. Plant Physiol. 164:728-736.

Gutiérrez-Coronado, M. A., Trejo-López, C. and Larqué-Saavedra, A. 1998. Effects of salicylic acid on the growth of roots and shoots in soybean. Plant Physiol. Biochem. 36:563-565. 
Hong, J. K. and Hwang, B. K. 2005. Induction of enhanced disease resistance and oxidative stress tolerance by overexpression of pepper basic PR-1 gene in Arabidopsis. Physiol. Plant. 124:267-277.

Horváth, E., Csiszár, J., Gallé, Á., Poór, P., Szepesi, Á. and Tari, I. 2015. Hardening with salicylic acid induces concentrationdependent changes in abscisic acid biosynthesis of tomato under salt stress. J. Plant Physiol. 183:54-63.

Horváth, E., Szalai, G. and Janda, T. 2007. Induction of abiotic stress tolerance by salicylic acid signaling. J. Plant Growth Regul. 26:290-300.

Jendoubi, W., Harbaoui, K. and Hamada, W. 2017. Salicylic acidinduced resistance against Fusarium oxysporumf.s.pradicis lycopercisi in hydroponic grown tomato plants. J. New Sci. Agric. Biotechnol. 21:985-995.

Jiang, C.-J., Shimono, M., Sugano, S., Kojima, M., Yazawa, K., Yoshida, R., Inoue, H., Hayashi, N., Sakakibara, H. and Takatsuji, H. 2010. Abscisic acid interacts antagonistically with salicylic acid signaling pathway in rice-Magnaporthe grisea interaction. Mol. Plant-Microbe Interact. 23:791-798.

Ju, C. and Chang, C. 2015. Mechanistic insights in ethylene perception and signal transduction. Plant Physiol. 169:85-95.

Kalachova, T., Puga-Freitas, R., Kravets, V., Soubigou-Taconnat, L., Repellin, A., Balzergue, S., Zachowski, A. and Ruelland, E. 2016. The inhibition of basal phosphoinositide-dependent phospholipase C activity in Arabidopsis suspension cells by abscisic or salicylic acid acts as a signalling hub accounting for an important overlap in transcriptome remodelling induced by these hormones. Environ. Exp. Bot. 123:37-49.

Kazemi, M. 2013. Foliar application of salicylic acid and calcium on yield, yield component and chemical properties of strawberry. Bull. Environ. Pharmacol. Life Sci. 2:19-23.

Khan, M. I. R., Fatma, M., Per, T. S., Anjum, N. A. and Khan, N. A. 2015. Salicylic acid-induced abiotic stress tolerance and underlying mechanisms in plants. Front. Plant Sci. 6:462.

Khanam, N. N., Ueno, M., Kihara, J., Honda, Y. and Arase, S. 2005. Suppression of red light-induced resistance in broad beans to Botrytis cinerea by salicylic acid. Physiol. Mol. Plant Pathol. 66:20-29.

Klessig, D. F., Choi, H. W. and Dempsey, D. A. 2018. Systemic acquired resistance and salicylic acid: past, present, and future. Mol. Plant-Microbe Interact. 31:871-888.

Kobeasy, M. I., El-Beltagi, H. S., El-Shazly, M. A. and Khattab, E. A. H. 2011. Induction of resistance in Arachis hypogaea L. against Peanut mottle virus by nitric oxide and salicylic acid. Physiol. Mol. Plant Pathol. 76:112-118.

Korver, R. A., Koevoets, I. T. and Testerink, C. 2018. Out of shape during stress: a key role for auxin. Trends Plant Sci. 23:783-793.

Kováčik, J., Klejdus, B., Hedbavny, J. and Bačkor, M. 2009. Salicylic acid alleviates $\mathrm{NaCl}$-induced changes in the metabolism of Matricaria chamomilla plants. Ecotoxicology 18:544-554.

Krantev, A., Yordanova, R., Janda, T., Szalai, G. and Popova, L. 2008. Treatment with salicylic acid decreases the effect of cadmium on photosynthesis in maize plants. J. Plant Physiol. 165:920-931.

Kundu, S., Chakraborty, D. and Pal, A. 2011. Proteomic analysis of salicylic acid induced resistance to Mungbean Yellow Mosaic India Virus in Vigna mungo. J. Proteomics 74:337-349.

Kunkel, B. N. and Brooks, D. M. 2002. Cross talk between signaling pathways in pathogen defense. Curr. Opin. Plant Biol. 5:325-331.

Le Thanh, T., Thumanu, K., Wongkaew, S., Boonkerd, N., Teaumroong, N., Phansak, P. and Buensanteai, N. 2017. Salicylic acid-induced accumulation of biochemical components associated with resistance against Xanthomonas oryzae pv. oryzae in rice. J. Plant Interact. 12:108-120.

Lebeis, S. L., Paredes, S. H., Lundberg, D. S., Breakfield, N., Gehring, J., McDonald, M., Malfatti, S., Glavina del Rio, T., Jones, C. D., Tringe, S. G. and Dangl, J. L. 2015. Salicylic acid modulates colonization of the root microbiome by specific bacterial taxa. Science 349:860-864.

Li, L. and Zou, Y. 2017. Induction of disease resistance by salicylic acid and calcium ion against Botrytis cinerea in tomato (Lycopersicon esculentum). Emir. J. Food Agric. 29:78-82.

Lu, H. 2009. Dissection of salicylic acid-mediated defense signaling networks. Plant Signal. Behav. 4:713-717.

Lundberg, D. S., Lebeis, S. L., Paredes, S. H., Yourstone, S., Gehring, J., Malfatti, S., Tremblay, J., Engelbrektson, A., Kunin, V., Del Rio, T. G., Edgar, R. C., Eickhorst, T., Ley, R. E., Hugenholtz, P., Tringe, S. G. and Dangl, J. L. 2012. Defining the core Arabidopsis thaliana root microbiome. Nature 488:8690.

Manzoor, K., Ilyas, N., Batool, N., Ahmad, B. and Arshad, M. 2015. Effect of salicylic acid on the growth and physiological characteristics of maize under stress conditions. J. Chem. Soc. Pakistan 37:588-593.

Metwally, A., Finkemeier, I., Georgi, M. and Dietz, K.-J. 2003. Salicylic acid alleviates the cadmium toxicity in barley seedlings. Plant Physiol. 132:272-281.

Mohan Babu, R., Sajeena, A., Vijaya Samundeeswari, A., Sreedhar, A., Vidhyasekaran, P., Seetharaman, K. and Reddy, M. S. 2003. Induction of systemic resistance to Xanthomonas oryzae pv. oryzae by salicylic acid in Oryza sativa (L.). J. Plant Dis. Prot. 110:419-431.

Ng, L. M., Melcher, K., Teh, B. T. and Xu, H. E. 2014. Abscisic acid perception and signaling: structural mechanisms and applications. Acta Pharmacol. Sin. 35:567-584.

Ngullie, C. R., Tank, R. V. and Bhanderi, D. R. 2014. Effect of salicylic acid and humic acid on flowering, fruiting, yield and quality of mango (Mangifera indica L.) cv. KESAR. $A d v$. Res. J. Crop Improv. 5:136-139.

Pasternak, T., Groot, E. P., Kazantsev, F. V., Teale, W., Omelyanchuk, N., Kovrizhnykh, V., Palme, K. and Mironova, V. V. 2019. Salicylic acid affects root meristem patterning via auxin distribution in a concentration-dependent manner. Plant Physiol. 180:1725-1739.

Pérez-Llorca, M., Muñoz, P., Müller, M. and Munné-Bosch, S. 
2019. Biosynthesis, metabolism and function of auxin, salicylic acid and melatonin in climacteric and non-climacteric fruits. Front. Plant Sci. 10:136.

Radwan, D. E. M., Fayez, K. A., Mahmoud, S. Y., Hamad, A. and Lu, G. 2007. Physiological and metabolic changes of Cucurbita pepo leaves in response to zucchini yellow mosaic virus (ZYMV) infection and salicylic acid treatments. Plant Physiol. Biochem. 45:480-489.

Rivas-San Vicente, M. and Plasencia, J. 2011. Salicylic acid beyond defence: its role in plant growth and development. J. Exp. Bot. 62:3321-3338.

Robert-Seilaniantz, A., Grant, M. and Jones, J. D. G. 2011. Hormone crosstalk in plant disease and defense: more than just jasmonate-salicylate antagonism. Annu. Rev. Phytopathol. 49:317-343.

Rothwell, P. M., Wilson, M., Elwin, C.-E., Norrving, B., Algra, A., Warlow, C. P. and Meade, T. W. 2010. Long-term effect of aspirin on colorectal cancer incidence and mortality: 20-year follow-up of five randomised trials. Lancet 376:1741-1750.

Saikia, R., Singh, T., Kumar, R., Srivastava, J., Srivastava, A. K., Singh, K. and Arora, D. K. 2003. Role of salicylic acid in systemic resistance induced by Pseudomonas fluorescens against Fusarium oxysporum f. sp. ciceri in chickpea. Microbiol. Res. 158:203-213.

Sakhabutdinova, A. R., Fatkhutdinova, D. R., Bezrukova, M. V. and Shakirova, F. M. 2003. Salicylic acid prevents the damaging action of stress factors on wheat plants. Bulg. J. Plant Physiol. 29(3-4 Spec issue):314-319.

Sallam, A. M. and Ibrahim, H. I. M. 2015. Effect of grain priming with salicylic acid on germination speed, seedling characters, anti-oxidant enzyme activity and forage yield of teosinte. Am. Eurasian J. Agric. Environ. Sci. 15:744-753.

Sarowar, S., Kim, Y. J., Kim, E. N., Kim, K. D., Hwang, B. K., Islam, R. and Shin, J. S. 2005. Overexpression of a pepper basic pathogenesis-related protein 1 gene in tobacco plants enhances resistance to heavy metal and pathogen stresses. Plant Cell Rep. 24:216-224.

Senaratna, T., Touchell, D., Bunn, E. and Dixon, K. 2000. Acetyl salicylic acid (Aspirin) and salicylic acid induce multiple stress tolerance in bean and tomato plants. Plant Growth Regul. 30:157-161.

Shaaban, M. M., Abd El-Aal, A. M. K. and Ahmed, F. F. 2011. Insight into the effect of salicylic acid on apple trees growing under sandy saline soil. Res. J. Agric. Biol. Sci. 7:150-156.

Steinberg, G. R., Dandapani, M. and Hardie, D. G. 2013. AMPK: mediating the metabolic effects of salicylate-based drugs? Trends Endocrinol. Metab. 24:481-487.

Stella de Freitas, T. F., Stout, M. J. and Sant'Ana, J. 2019. Effects of exogenous methyl jasmonate and salicylic acid on rice resistance to Oebalus pugnax. Pest Manag. Sci. 75:744-752.

Szalai, G., Pál, M. and Janda, T. 2011. Abscisic acid may alter the salicylic acid-related abiotic stress response in maize. Acta Biol. Szeged. 55:155-157.

Tschanz, J. T., Norton, M. C., Zandi, P. P. and Lyketsos, C. G.
2013. The Cache County Study on Memory in Aging: factors affecting risk of Alzheimer's disease and its progression after onset. Int. Rev. Psychiatry 25:673-685.

Ulferts, S., Delventhal, R., Splivallo, R., Karlovsky, P. and Schaffrath, U. 2015. Abscisic acid negatively interferes with basal defence of barley against Magnaporthe oryzae. BMC Plant Biol. 15:7.

Vlot, A. C., Dempsey, D. A. and Klessig, D. F. 2009. Salicylic Acid, a multifaceted hormone to combat disease. Annu. Rev. Phytopathol. 47:177-206.

Wang, C., Liu, Y., Li, S. S. and Han, G. Z. 2015a. Insights into the origin and evolution of the plant hormone signaling machinery. Plant Physiol. 167:872-886.

Wang, J., Chen, S.-H., Huang, Y.-F. and Sun, S. 2006. Induced resistance to anthracnose of Camelia oleifera by salicylic acid. For. Res. 19:629-632.

Wang, K. L.-C., Li, H. and Ecker, J. R. 2002. Ethylene biosynthesis and signaling networks. Plant Cell 14 Suppl: S131-S151.

Wang, W., Wang, X., Huang, M., Cai, J., Zhou, Q., Dai, T., Cao, W. and Jiang, D. 2018. Hydrogen peroxide and abscisic acid mediate salicylic acid-induced freezing tolerance in wheat. Front. Plant Sci. 9:1137.

Wang, Y. and Liu, J.-H. 2012. Exogenous treatment with salicylic acid attenuates occurrence of citrus canker in susceptible navel orange (Citrus sinensis Osbeck). J. Plant Physiol. 169:1143-1149.

Wang, Z., Jia, C., Li, J., Huang, S., Xu, B. and Jin, Z. 2015 b. Activation of salicylic acid metabolism and signal transduction can enhance resistance to Fusarium wilt in banana (Musa acuminata L. AAA group, cv. Cavendish). Funct. Integr. Genomics 15:47-62.

Wasternack, C. and Song, S. 2017. Jasmonates: biosynthesis, metabolism, and signaling by proteins activating and repressing transcription. J. Exp. Bot. 68:1303-1321.

Went, F. W. and Thimann, K. V. 1937. Phytohormones. Macmillan, New York, NY, USA. 294 pp.

Wu, J., Kim, S. G., Kang, K. Y., Kim, J.-G., Park, S.-R., Gupta, R., Kim, Y. H., Wang, Y. and Kim, S. T. 2016. Overexpression of a pathogenesis-related protein 10 enhances biotic and abiotic stress tolerance in rice. Plant Pathol. J. 32:552-562.

Wu, W., Ding, Y., Wei, W., Davis, R. E., Lee, I.-M., Hammond, R. W. and Zhao, Y. 2012. Salicylic acid-mediated elicitation of tomato defence against infection by potato purple top phytoplasma. Ann. Appl. Biol. 161:36-45.

Xie, Z., Zhang, Z.-L., Hanzlik, S., Cook, E. and Shen, Q. J. 2007. Salicylic acid inhibits gibberellin-induced alpha-amylase expression and seed germination via a pathway involving an abscisic-acid-inducible WRKY gene. Plant Mol. Biol. 64:293303.

Xiong, L. and Zhu, J.-K. 2003. Regulation of abscisic acid biosynthesis. Plant Physiol. 133:29-36.

Yan, S. and Dong, X. 2014. Perception of the plant immune signal salicylic acid. Curr. Opin. Plant Biol. 20:64-68.

Yildirim, E., Ekinci, M., Turan, M., Dursun, A., Kul, R. and Par- 
lakova, F. 2015. Roles of glycine betaine in mitigating deleterious effect of salt stress on lettuce (Lactuca sativa L.). Arch. Agron. Soil Sci. 61:1673-1689.

Yildirim, E., Turan, M. and Guvenc, I. 2008. Effect of foliar salicylic acid applications on growth, chlorophyll, and mineral content of cucumber grown under salt stress. J. Plant Nutr. 31:593-612.
Yousif, D. Y. M. 2018. Effects sprayed solution of salicylic acid to prevent of wilt disease caused by Fussarium oxysporium. J. Phys. Conf. Ser. 1003:012001.

Zhang, Y. and Li, X. 2019. Salicylic acid: biosynthesis, perception, and contributions to plant immunity. Curr. Opin. Plant Biol. 50:29-36. 